\title{
El tabernáculo de Guillermo de Orta para la capilla del Sagrario de la catedral de Córdoba*
}

\author{
Guillermo de Orta's tabernacle for the \\ sanctuary chapel in Cordoba cathedral
}

\author{
Fernando MORENO CUADRO \\ Universidad de Córdoba \\ it1mocuf@uco.es
}

\begin{abstract}
This work focuses on the tabernacle in the Sanctuary of Cordoba Cathedral as an image of the Holy Sepulchre of Jerusalem, in the context of the Sanctuary Chapel. This was designed as a House of Wisdom inside the Cathedral, which in the sixteenth century was thought of as the "New Jerusalem of Cordoba'. In this century, it became one of the key venues for the liturgical ceremonies held in the sanctified area of the old Mosque of Cordoba, and this celestial city was identified closely with the real city.
\end{abstract}

Keywords: Holy Sepulchre; House of Wisdom; celestial Jerusalem.
Resumen: El trabajo se centra en el análisis del tabernáculo del Sagrario de la catedral de Córdoba como imagen del Santo Sepulcro de Jerusalén, en el contexto de la capilla del Sagrario que se concibe como Casa de la Sabiduría y del conjunto catedralicio que se presenta como la Nueva Jerusalén de Córdoba en el siglo XVI, centuria en la que se convierte en uno de los puntos neurálgicos del ceremonial litúrgico celebrado en el espacio sacralizado de la antigua aljama de Córdoba, identificándose la ciudad celeste con la ciudad real.

Palabras clave: Santo Sepulcro; Casa de la Sabiduría; Jerusalén celeste.

El tabernáculo que ocupa nuestra atención es una de las piezas más singulares de la catedral de Córdoba, no solo por su calidad artística sino también por el significado simbólico que tuvo en la liturgia postridentina, en la que se consideró como uno de los puntos neurálgicos del ceremonial catedralicio, aunque en la actualidad cumple las funciones de sagrario de la parroquia que se integra en el recinto de la catedral con el mismo nombre de la capilla que lo alberga.

El primer sagrario de la catedral se ubicó en la capilla de San Pedro, situada en la macsura de la antigua aljama de Córdoba, emplazamiento lógico por la importancia del lugar y la proximidad a la primera capilla mayor que, tras la segunda

* Este trabajo se inscribe en el marco del Proyecto de Investigación HAR2015-68577, financiado por el Ministerio de Economía y Competitividad. 
consagración de la excepcional edificación islámica ${ }^{1}$, se instituyó en el lucernario de Al-Haken II, que a partir de 1607, cuando se terminó el nuevo crucero, se dedicó a Nuestra Señora de Villaviciosa.

En un primer momento, la capilla del Sagrario catedralicia estuvo destinada a la reserva eucarística de las hostias consagradas que se destinaban a la distribución de la comunión, administración del viático y adoración eucarística, coincidiendo la denominación generalizada de la capilla donde se reservaba el Santísimo, independientemente de la advocación a la que estuviera dedicada, con el arca en la que se depositaban las hostias -en principio de madera- que se empotraba de forma habitual en el testero oriental de las capillas en las que se veneraba, como se recoge en los inventarios parroquiales ${ }^{2}$.

Durante el Medievo los fieles no participaban asiduamente de la Eucaristía y los textos sinodales de Toledo de fines del s. XIV solo recogen en la preparación de la celebración la hostia del celebrante ${ }^{3}$. Por ello, la reserva se hacía especialmente para la adoración y administración del viático en pequeñas píxides y relicarios eucarísticos. Luego aparecieron los copones, pequeños hasta fines del siglo XVI, momento en el que aumentan de tamaño por las reformas tridentinas y el impulso de la comunión frecuente que defendieron importantes personalidades como san Ignacio de Loyola ${ }^{4}$ el Maestro Juan de Ávila ${ }^{5}$.

En este contexto hay que situar la nueva capilla del Sagrario de la catedral de Córdoba, ubicada en el lugar de la antigua capilla de Santiago, donde el Cabildo pretendió trasladar la Biblioteca Capitular desde finales del siglo XV, aunque no sería hasta 1516-1517 cuando se lleva a cabo la reforma destinada a acoger la importante donación de libros realizada por don Martín Fernández de Angulo, quien rigió la diócesis entre 1510 y 1516; pero el proyecto se truncó por la decisión capitular de instalar en dicho lugar el Sagrario de la catedral y los fondos bibliográficos se trasladaron a las cámaras catedralicias.

1 La antigua mezquita de Córdoba fue dedicada al culto cristiano en dos ocasiones: tras la conquista de la ciudad a los almorávides (1146) y a los almohades (1236), aunque solo puede considerarse catedral a partir de la restauración de la sede episcopal en 1239, cuando Lope de Fitero fue consagrado obispo de la misma por el arzobispo de Toledo Rodrigo Jiménez de Rada.

2 Manuel Nieto Cumplido y Fernando Moreno CuAdro, Eucharistica cordubensis, Publicaciones del Monte de Piedad y Caja de Ahorros de Córdoba, Córdoba, 1993, p. 155.

3 Ibid., p. 98.

4 Justo Beguiriztáin, El apostolado eucarístico de san Ignacio de Loyola, Sebastián de Amorrortu, Buenos Aires, 1945.

5 Juan Esquerda Bifet, Comunión eucarística, en Diccionario de San fuan de Ávila, Monte Carmelo, Burgos, 1999, pp. 192-194. 
Los preparativos para la nueva capilla del Sagrario, a la que se uniría la feligresía de la catedral, están documentados desde 1571, encargándose a Hernán Ruiz III la portada en 1573 y a Fernando de Valencia en 1580 la reja, que concluyó Juan Martínez en 1581, durante el pontificado de don Martín de Córdoba y Mendoza (1578-1581) ${ }^{6}$, cuyo escudo figura en la misma ${ }^{7}$.

En 1578 se contrató el tabernáculo a Guillermo de Orta, que se doró, estofó y pintó en 1583 por Alonso de Ribera ${ }^{8}$, produciéndose a partir de este momento el encargo de la decoración de la capilla a César Arbasia9 ${ }^{9}$ el amigo de Pablo de Céspedes, que ese mismo año viajó a Roma, donde residió hasta 1592, aunque pudo intervenir en el programa decorativo junto a Ambrosio de Morales, con «quien arregló el quaderno de los santos mártires de Córdoba» ${ }^{10}$, como lo hizo en la última fase del nuevo crucero catedralicio ${ }^{11}$, en cuyo programa iconográfico se introduce la iglesia diocesana a través de sus mártires, de los que se habían encontrado sus enterramientos en la iglesia parroquial de San Pedro con motivo de las obras realizadas en 1575 para asegurar el arco toral de la nave de la epístola que había quedado resentido por unas reformas hechas en la torre años antes, poco tiempo después de que Ambrosio de Morales publicara La opera omnia de san Eulogio en Alcalá de Henares, acrecentándose su devoción en 1578 con las

6 Manuel Nieto Cumplido, La Catedral de Córdoba, Córdoba, Publicaciones CajaSur, 2007, pp. 382-384.

7 Juan Andrés Molinero Merchán, La Mezquita-Catedral de Córdoba: Símbolos de poder. Estudio Histórico-Artístico a través de sus armerías, Servicio de Publicaciones de la Universidad y Ayuntamiento de Córdoba, Córdoba, 2005, pp. 381-382.

8 ARCHIVO PROVINCIAL DE CÓRDOBA (=APC), Oficio 4, t. 17, ff. 241-243 y t. 26, ff. 1149-1150, cfr. José DE LA TORRE, Registro Documental de pintores cordobeses, Diputación Provincial, Córdoba, 1988, pp. 188 y 201. ARCHIVO CAPITULAR CÓRDOBA (=ACC), Cuentas de fábrica, 23 de diciembre de 1581 .

9 APC, Oficio 22, t. 21, s.f., cfr. José DE LA TORRE, Registro Documental..., op. cit., nota 9, p. 201, y APC, Oficio 4, t. 30, ff. 1078-1081, cfr. José DE LA TORRE, Registro Documental, cit. nota 9, p. 203. Véase también Francisco Javier SÁNCHEZ CANTÓn, El obispo Pazos, el cronista Morales y el pintor César Arbasia, en Archivo Español de Arte y Arqueología, 37 (1937), pp. 73-74. El prestigioso historiador del arte dio a conocer una nota manuscrita de Ambrosio de Morales (BIBLIOTECA NACIONAL, Ms 5785, f. 125) que confirma la autoría del pintor saluzzesi: «Venido el obispo don Antonio de Pazos mandó dar priesa en acabar ricamente el Sagrario y por un pintor piamontés llamado César Arbasia se doraron y pintaron las bóvedas con un cielo de ángeles y las paredes con los Santos Mártires de Córdoba, dando yo los sujetos para pintura y escritura».

10 Juan Agustín CEÁN BermúdeZ, Diccionario histórico de los más ilustres profesores de las bellas artes... 1800, Edición de Madrid, Madrid, 1965, t. I. p. 318.

11 Fernando MORENo CUADRO, El crucero de la catedral de Córdoba: estudio iconográfico e iconológico, en Cuadernos de Arte e Iconografía, XVI/31 (2007), monográfico primer semestre, vid. esp. pp. 201222. 
revelaciones sobre la autenticidad de las reliquias del arcángel san Rafael al padre Andrés de Roelas ${ }^{12}$.

Todo ello y el impulso que recibió su culto, aprobado en 1583 por el Concilio Provincial de Toledo ${ }^{13}$, determinó el programa visual de la nueva capilla del Sagrario y la inclusión de los mártires en el crucero catedralicio, del que no se puede desvincular la capilla, no solo por su cronología y desarrollo iconográfico con la presencia de la iglesia particular de Córdoba, sino también, y especialmente, por el ceremonial litúrgico del que formaba parte fundamental, lo que pensamos determina la ubicación y forma del tabernáculo que analizamos.

\section{El TABERNÁCUlo IMAGEN DEL SANTO SEPUlCRO DE JERUSAlÉN}

Desde el punto de vista formal, el tabernáculo está formado por un semitemplete circular con dos cuerpos decrecientes en medio de un espacio cuadrangular o capilla abierta en el muro.

No creemos necesario explicar en este lugar el significado de los dos símbolos primordiales ${ }^{14}$ ni su utilización en San Pietro in Montorio de Roma ${ }^{15}$, pero sí recordar una de las construcciones del mundo tardoantiguo que más influencia ha tenido en el arte, la rotonda constantiniana del Santo Sepulcro, que señalaba el lugar donde Cristo fue enterrado y resucitó ${ }^{16}$. Delante de la citada estructura centralizada había un patio que comunicaba con la capilla del Calvario y la basílica martirial, desde la que se accedía a la capilla de Santa Elena, el lugar donde fue encontrada la verdadera cruz, y todo ello estaba precedido por un atrio que comunicaba con la ciudad.

Con la llegada de los cruzados y su conquista de Jerusalén en el 1099 comenzaron las reformas que cambiaron la imagen del prestigioso complejo arquitectó-

$12 \mathrm{Al}$ respecto, véase Gerónimo de VILCHES, Triunfo angélico del celeste príncipe, poderoso protector y glorioso custodio de la ciudad de Córdoba, San Rafael, Juan Rodríguez, Córdoba, 1781.

13 Decreto recogido por Antonio Moyano RUIZ, Opúsculo martirial en bonor de las reliquias de los Santos Mártires de Córdoba, publicado por la Hermandad del Santísimo Sacramento y Santos Mártires de Córdoba, Imprenta San Pablo, Córdoba, 1959, pp. 13-16.

$14 \mathrm{Al}$ respecto, véase Gérard de CHAMPEAUX, Introduction au monde des symboles, Zodiaque, Introductions à la nuit des temps, $2^{\text {a }}$ ed., Parution, París, 1972.

15 Giuseppe FoRTUNATO, The Role of Architectural Representation in the Analysis of the Building: The $3 d$ Survey of San Pietro in Montorio's Temple in Rome, en Actas del X Congreso Internacional de expresión gráfica aplicada a la edificación, Marfil, Alicante, 2010, pp. 451-460.

16 Una panorámica completa del conjunto en André PARROT, El Gólgota y el Santo Sepulcro, Garriga, Barcelona, 1963. 
EL TABERNÁCULO DE GUILLERMO DE ORTA PARA LA CAPILLA DEL SAGRARIO...

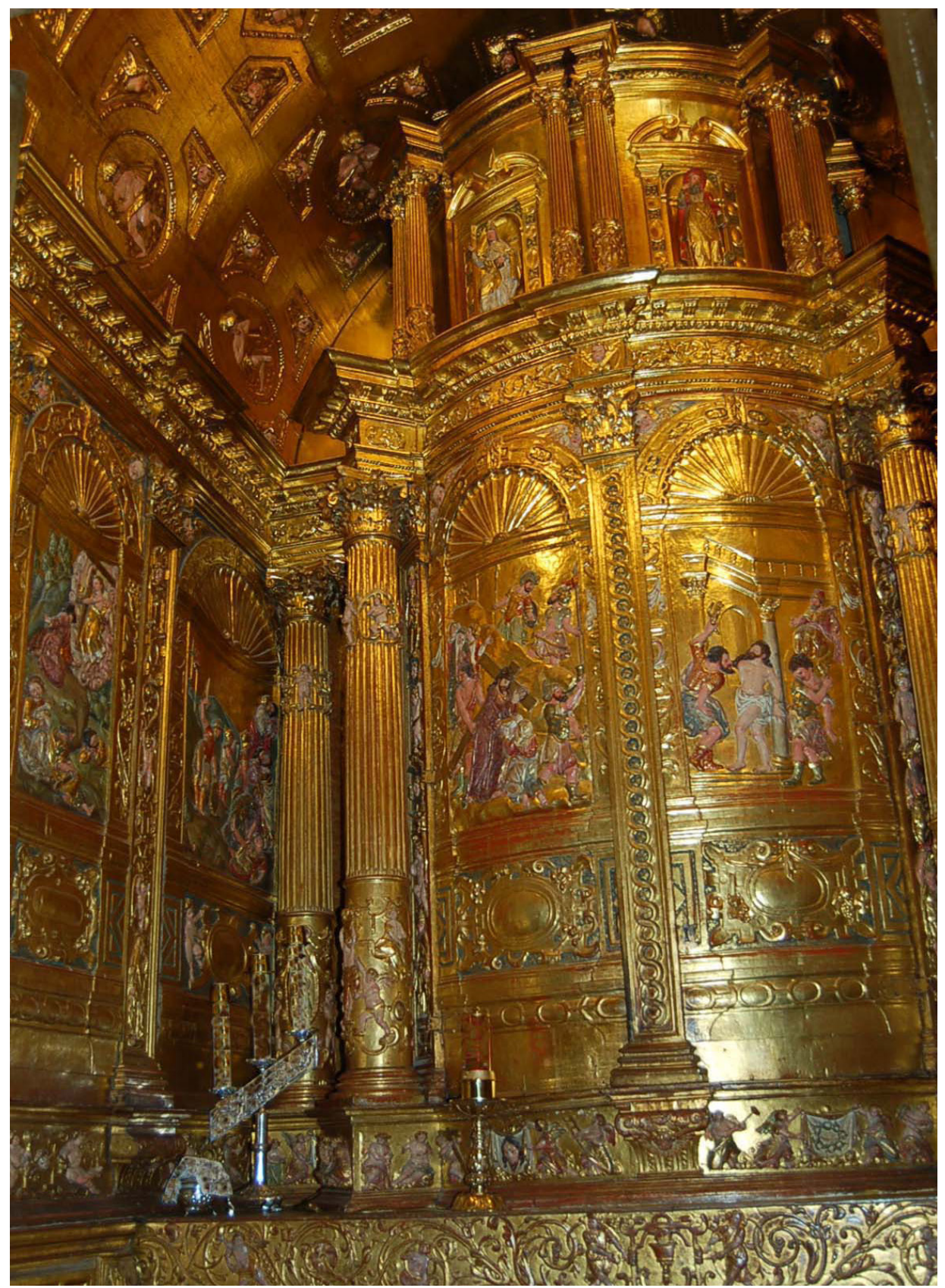

Guillermo de Orta. Tabernáculo de la capilla del Sagrario de la catedral de Córdoba, 1578-1583. Dorado, estofado y pintura de Alonso de Ribera. 
nico $^{17}$, centro fundamental de peregrinaciones. Por el significado simbólico de este espacio, no es de extrañar que para el lugar de la reserva de las hostias consagradas se pensara hacer una microarquitectura que recordara el Santo Sepulcro, con una estructura de templete de dos cuerpos, como había empleado Bramante en el tempietto de San Pietro in Montorio de Roma, patrocinado por los Reyes Católicos, especialmente difundido en España a partir de la publicación del Tercer y Qvarto Libro de Architectura de Sebastian Serlio ${ }^{18}$, con el que encontramos alguna semejanza, aunque por su finalidad y localización el tabernáculo presenta una singular decoración, acorde con su destino, de la que carece el tempietto romano.

El templete se ubica al fondo de un cuadrado, que se correspondería con el patio que precedía la rotonda de la Anástasis y la conectaba con la basílica martirial, que sería parangonable en la catedral cordobesa con la capilla del Sagrario, decorada con los mártires de Córdoba. El martyrium hierosolimitano estaba asimismo precedido por un atrio que lo conectaba con la ciudad, que en Córdoba se identificaría con el espacio anterior a la capilla del Sagrario -cuya decoración contrató Arbasia ${ }^{19}$ con la colaboración de Mohedano y los hermanos Juan Bautista y Francisco Peroli ${ }^{20}$ - que enlazaba la nueva capilla con el resto del recinto catedralicio, imagen de la Jerusalén Celeste que se hace corresponder con la Jerusalén real, aspecto en el que insistiremos más adelante.

La decoración, hasta la fecha, se ha resumido de manera muy simple, en nuestra opinión, explicando que en el tabernáculo se presenta un programa pasionista que recoge los principales momentos de la Pasión y prefiguras eucarísticas que relacionan la Pasión con la Eucaristía ${ }^{21}$, y un estremecedor viacrucis ${ }^{22}$, pero estamos convencidos que la falta de ordenación clara en la secuenciación de los relieves, que se distribuyen en tres grandes bloques, se debe a una intencionalidad concreta, la de mostrar la Pasión de Cristo como camino a seguir para alcanzar la gloria, el camino seguido por los mártires que decoran la capilla del

17 Paul Deschamps, Terre Sainte Romane, Zodiaque, París, 1964, p. 241.

18 Sebastián SERLIO, Tercer y Qvarto Libro de Architectura, Juan de Ayala, Toledo, 1573. Libro Tercero de las Antigüedades, XXIII-XXIIII.

19 APC, Oficio 4, t. 31, ff. 356-357, cfr. José DE LA TORRE, Registro Documental de pintores cordobeses, cit. nota 9, pp. 204-205.

20 Las pinturas de profetas e historias de las Sagradas Escrituras, alusivas al Sacramento, fueron recogidas por Antonio PALOMINO, Vidas, Alianza Editorial, Madrid, 1986, pp.72-73, aunque en el siglo XIX fueron raspadas por encontrarse muy deterioradas.

21 Manuel PÉREZ Lozano, Los programas iconográficos de la Capilla del Sagrario de la Catedral de Córdoba, en Cuadernos de Arte e Iconografía, IV/8 (1991), pp. 57-64, vid p. 58

22 Bartolomé Menor Borrego, El Templo Parroquial de El Sagrario de la Santa Iglesia Catedral de Córdoba, Publicaciones Obra Social y Cultural CajaSur, Córdoba, 2003, p. 48. 
Sagrario y que se presentan como ejemplo a la iglesia diocesana ${ }^{23}$, no planteándose como un programa visual independiente sino como una parte del conjunto de obras que se desarrolla en la época.

En relación al sentido de ejemplaridad, podemos recordar a san Agustín cuando explica la plenitud del amor en su Tratado sobre el evangelio de san Fuan. El obispo de Hipona subraya las palabras del discípulo predilecto, «Cristo dio su vida por nosotros; también nosotros debemos dar nuestra vida por los hermanos, amándonos mutuamente como él nos amó», y explica las palabras de Pedro, quien dijo «Cristo padeció por nosotros, dejándonos un ejemplo para que sigamos sus huellas. Esto significa preparar algo semejante. Esto es lo que hicieron los mártires, llevados de un amor ardiente», añadiendo finalmente que «Los mártires, al derramar su sangre por sus hermanos, no hicieron sino mostrar lo que habían tomado de la mesa del Señor. Amémonos, pues, los unos a los otros, como Cristo nos amó y se entregó por nosotros» ${ }^{24}$. Así pues, teniendo presente a san Agustín, que se ha figurado en la parte superior del templete, proponemos una nueva lectura de la decoración del tabernáculo.

En los laterales se presentan tres relieves a cada lado que figuran el comienzo y culminación de la Pasión y muerte de Cristo en la cruz. Los relieves centrales muestran los momentos cruciales, la Oración en Getsemaní y la Crucifixión, con la que termina la agonía y el sufrimiento comenzado en el Huerto de los Olivos, preámbulo trascendental de la Pasión que se debe convertir en norma de conducta para los cristianos, pues la oración de Cristo preparándose con el Padre (Mc 14,36) es el prototipo de las oraciones de todos los cristianos, quienes con la mirada puesta en Getsemaní aceptan su voluntad, haciendo suyo Getsemaní, no importando el abandono, los insultos y desprecios, presentándose los mártires cordobeses en las decoraciones catedralicias como seguidores de Cristo que sirven de ejemplo a la iglesia diocesana, en un momento que coincide con la aparición de las reliquias de los Santos Mártires en la iglesia de San Pedro en 1575 y el desarrollo de su devoción en la ciudad de Córdoba, como hemos comentado.

23 Ambrosio de Morales, en la dedicatoria fechada en agosto de 1584, en una de sus estancias en Córdoba, del t. IV de la Crónica General de España, en el que trata la dominación musulmana e incluye los mártires de la época, al obispo don Antonio de Pazos y Figueroa (1582-1585), insiste en este aspecto al recordar su intervención en la capilla: «También los mandó pintar y escrevir debaxo dellos sus historias sumadas, en el riquísimo sagrario nuevo de la iglesia mayor; donde sola la lindeza y magestad de toda la obra es una cosa de las más señaladas que ay en España con admiración de todos los que la ven. Mas la devoción que con esto se ha despertado en toda la ciudad para sus santos, es tan grande, que se puede estimar por mucho más preciosa; pues con el recuerdo de la pintura y de la historia levanta las almas al cielo».

24 SAN AGUSTÍN DE HIPONA, Tratado 84 sobre el evangelio de san fuan, 1-2: CCL 36, 536-538. 


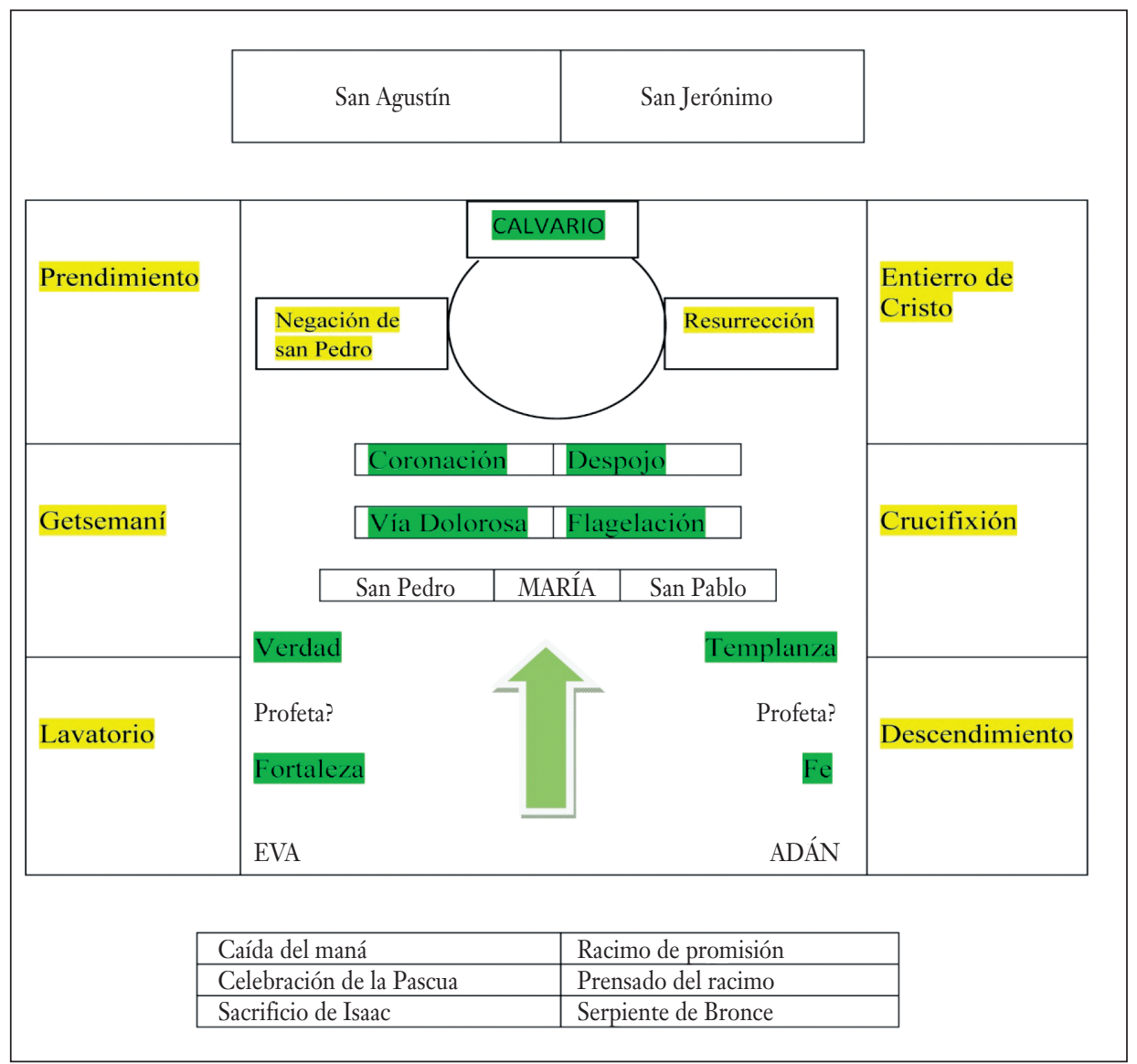

Esquema iconográfico del tabernáculo de la capilla del Sagrario.

La Oración en Getsemaní está flanqueada por el Prendimiento y el lavatorio de Pilato, conjunto de relieves que se completa en el exterior del templete circular con la negación de san Pedro, que no se presenta con la intención de dejar en mal lugar al primer papa, sino como muestra de debilidad que hay que superar, como lo hizo san Pedro, una temática recogida ampliamente por el arte cristiano para mostrar el arrepentimiento, especialmente sintetizada por las Lágrimas de san Pedro ${ }^{25}$.

$25 \mathrm{Al}$ respecto, véase Las lágrimas de San Pedro en la pintura española del Siglo de Oro, Bilbao, Museo de Bellas Artes, 2000. 
En el lateral opuesto se ha representado la Crucifixión flanqueada por el Descendimiento y el Entierro de Cristo, que se continúa con la Resurrección del Señor en el exterior del templete circular. Equidistante al comentado relieve petrino que muestra la superación de la flaqueza del apóstol que Cristo eligió (Mt 16,18-19) para gobernar la Iglesia.

Un lugar preferente, por su importante ubicación y visibilidad, tienen los relieves que decoran las puertas del templete circular, tanto exteriormente como en la parte interior. Cuando las puertas están cerradas, el fiel contempla los relieves de la Flagelación y la Vía Dolorosa, ejemplos muy significativos del sufrimiento y camino hacia la muerte, representada en el Calvario interior del mismo. $\mathrm{Al}$ abrirse, las puertas muestran la Coronación y el Despojo de las vestiduras, insistiendo en el dolor y desprendimiento de todo lo material, que para los cristianos representa la renuncia al mundo para llenarse del espíritu de Cristo.

La participación en la vida de Cristo se presenta como el camino a seguir, convirtiéndose la humanidad de Cristo en el programa de vida de numerosos san$\operatorname{tos}^{26}$ y mártires, quienes fortalecidos con las virtudes y continuando los ejemplos del Antiguo y Nuevo Testamento pueden alcanzar su fin con la ayuda de María.

En este sentido es muy significativa la disposición de los restantes relieves. En el centro del frontal que sirve de basamento al templete que alberga la Eucaristía, se ha representado María, flanqueada por los pilares de la Iglesia, mientras que bajo los relieves laterales que muestran el comienzo y culminación de la Pasión se han representado dos personajes veterotestamentarios junto a las figuras alegóricas de virtudes que posibilitan el logro de la meta, seguir a Cristo para gozar en Él: verdad, fortaleza, templanza y fe, que no será necesaria cuando se goce de la presencia de Dios, momento en el que solo prevalece la Caridad, según la teoría paulina de prevalencia de Caridad sobre las otras virtudes teologales (1 Cor 13,1-13).

Se presenta el camino que habían seguido las prefiguras anticotestamentarias comentadas, que podrían simbolizar a destacados profetas, como Daniel, que tuvo un especial tratamiento en la bóveda del coro catedralicio, o Jonás que fue enviado a Nínive por Yahvé, a quien desobedeció viajando a Tarsis, momento en el que se produjo una tormenta y para calmarla fue arrojado al mar, donde fue engullido por una ballena durante tres días, permanencia que Cristo comparó con su entierro y

26 Sirva de ejemplo santa Teresa de Jesús, quien siguiendo las enseñanzas de Cristo, recorre el camino de cruz como el camino de perfección: «gran fundamento es, para librarse de los ardides y gustos que da el demonio, el comenzar con determinación de llevar camino de cruz desde el principio y no los desear, pues el mismo Señor mostró ese camino de perfección diciendo: Toma tu cruz y sígueme. Él es nuestro dechado; no bay que temer quien por sólo contentarle siguiere sus consejos» (Vida 15, 13). 
resurrección. «así como Jonás estuvo en el vientre del cetáceo tres días y tres noches, así estará el Hijo del hombre tres días y tres noches en el corazón de la tierra» (Mt 12,40), considerándose una prefigura de Cristo, muy frecuente en el simbolismo tipológico que vincula el Antiguo y Nuevo Testamento y que se desarrolló especialmente en la Biblia Pauperum, siendo fundamental para nuestro análisis tener presente la presencia real de Cristo en la Eucaristía, que para los cristianos es la gran señal de la resurrección del Señor, que se manifiesta vivo y presente en la comida comunitaria ${ }^{27}$, presidida por el tabernáculo que analizamos.

Daniel tiene un papel fundamental en la coetánea bóveda del crucero catedralicio, donde aparece siguiendo el tradicional tipo iconográfico que lo figura en el foso de los leones, presentándose como un mensaje de esperanza a los judíos perseguidos, como los mártires cordobeses por sus enemigos, como un exiliado en la corte de Babilonia, donde gozó de mucha consideración por su ejercicio de interpretación de sueños, en un momento en el que tanta importancia tuvo en Córdoba la visión del padre Roelas (1525-1587), a quien en 1578, aquejado por una enfermedad, se le apareció san Rafael acompañado por unos caballeros -mártires- tras la que recuperó la salud y en la que recibió el encargo de comunicar a las autoridades eclesiásticas que se veneraran dignamente las reliquias halladas en la iglesia de San Pedro, ya que librarían a la ciudad de la peste, lo que aconteció durante la construcción de la cubierta del coro, según recoge Díaz de Ribas: «Esta profecía se cumplió después, por el año 1602, en una gran peste que hubo en esta ciudad, donde por último remedio de ella fueron sacados en procesión los huesos de los Santos Mártires, y luego cesó la enfermedad» ${ }^{28}$.

Por otro lado, Daniel fue alimentado por Habacuc en el foso de los leones en su segunda condena de castigo durante el reinado de Ciro, cuando fue acusado de haber envenenado la serpiente sagrada del dios Baal. Estuvo en el foso seis días rodeado por siete leones hambrientos ${ }^{29}$, durante los cuales recibió alimento de Habacuc, a quien un ángel trasportó desde Judea a Babilonia. Escena que se interpreta como un símbolo eucarístico, una prefiguración de la Cena y el alivio que la plegaria aporta a las almas.

27 Sobre la Eucaristía y la aparición del Resucitado, véase Medard KEHL, S. I., Eucharistie und Auferstehung. Zur Deutung der Ostererscheiungen bein Malbl, en Geist und Leben. Zeitschrift für christliche Spiritualität, 43 (1970), pp. 90-125.

28 P. DÍAZ DE RiBAS, El Arcángel S. Rafael, particular custodio y amparo de la Ciudad de Córdoba, Córdoba, Salvador de Cea Tesa, 1650, p. 37.

29 Durante la edad media se interpretó el foso como una imagen del infierno y los siete leones como los diablos que se corresponden con los pecados capitales: Lujuria (Asmodeo), Pereza (Belfegor), Gula (Belcebú), Ira (Amón), Envidia (Leviatán), Avaricia (Mammón) y Soberbia/orgullo (Lucifer). 
Recapitulando, lo que se presenta en el programa visual del tabernáculo es el camino para seguir a Cristo con el apoyo de las virtudes y los ejemplos del Antiguo y Nuevo Testamento, especialmente representado por los pilares de la Iglesia -San Pedro y san Pablo- que flanquean en el frontal sobre el que se apoya el templete la imagen de María, cuyo fiat hizo posible la obra de la Salvación con el sacrificio de Cristo en la Cruz para redimir a la Humanidad tras el pecado de Adán y Eva, que se han figurado en el extremo opuesto al Calvario.

El compartir con Cristo y con la Iglesia está para san Agustín en la celebración eucarística, en la que se rememora el sacrificio de Cristo y se produce la transubstanciación, por la que las especies del pan y el vino se convierten en la sangre y el cuerpo de Cristo, presente real y substancialmente en la Eucaristía -cuerpo, sangre, alma y divinidad de Jesucristo-, que para el obispo de Hipona es comunión con Cristo y a través de Él con la Iglesia.

Como es frecuente en muchas manifestaciones artísticas, encontramos la confrontación tipológica entre Antiguo y Nuevo Testamento, derivada de la interpretación alegórica de la Biblia al establecer una relación de pasajes de ambos Testamentos. La premisa de la división en dos partes de la historia de la humanidad llevó a pensar que deberían estar en armonía, planteándose que todo aquello que estaba velado en el AT fue revelado en el NT, ya que obedecían a un mismo pensamiento divino. Los diferentes textos revelados por Dios en el AT convergen en el Mesías. Cristocentrismo que constituye la espina dorsal del pensamiento cristiano.

Esta correlación/correspondencia entre AT y NT fue el sistema de interpretación de los textos bíblicos más utilizado hasta Trento desde los primeros momentos del cristianismo y fue impulsado por el mismo Cristo, quien dijo a sus discípulos que no había venido a abolir la Antigua Ley ni los profetas, sino a cumplirla (Mt 5,17).

En este sentido, las puertas del tabernáculo presentan importantes prefiguras eucarísticas: Racimo de promisión, prensado de la uva, caída del maná, celebración de la Pascua, sacrificio de Isaac y Serpiente de bronce.

La Eucaristía es el núcleo central del tabernáculo, cuyo segundo cuerpo se decora con las esculturas de san Agustín y san Jerónimo, dos de los Santos Padres más significativos por sus comentarios eucarísticos.

Para san Agustín la Eucaristía es símbolo de la unión con Cristo, «El que come mi carne y bebe mi sangre, permanece en mí y yo en él» (Jn 6,56), y el sacramento que nos une para que podamos reconocer a Cristo, y cuando afirma de forma explícita la presencia real de Cristo en las especies eucarísticas añade que «quiso el Señor dejarnos su cuerpo y su sangre... Si los habéis recibido dig- 
namente sois eso que habéis recibido $»^{30} \mathrm{e}$ invita a los fieles a «recibid y bebed la sangre de Cristo. No os desvinculéis, comed el vínculo que os une; no os estiméis en poco, bebed vuestro precio. A la manera como se transforma en vosotros cualquier cosa que coméis o bebéis, transformaos también vosotros en el cuerpo de Cristo viviendo en actitud obediente y piadosa $\gg^{31}$.

La Eucaristía es el sacramento que nos une para que podamos reconocer a Cristo, anotando sobre el encuentro de Emaús (Lc 24, 13-35) que «Cuando aquellos dos le reconocieron en la fracción del pan, nadie debe dudar de que se trataba del sacramento que a todos nos reúne cuando lo conocemos» ${ }^{32}$. Toda la Iglesia es por medio de la Eucaristía verdadero cuerpo de Cristo ${ }^{33}$, en quien está la vida -«cómete la vida, bébete la vida ${ }^{34}$ para tener una vida auténtica-. La Eucaristía es el centro vital y dinámico de la Iglesia, unión de los cristianos y de estos con Cristo.

La doctrina eucarística de san Jerónimo, gran conocedor de las Sagradas Escrituras, se puede sintetizar, con el riesgo que conlleva la simplificación, en uno de sus comentarios al Eclesiastés, cuando escribe que lo único bueno en la vida es comer y beber el cuerpo y la sangre de Cristo, no solo en el misterio de la Eucaristía sino también en la lectura de las Escrituras ${ }^{35}$, alimento para el espíritu y vida del cristiano, pues para el traductor bíblico quien desconoce las Escrituras desconoce a Cristo y en la liturgia de la palabra se come la carne del Señor, alimento del espíritu que es necesario para la salvación. No hay que separar, por tanto, la Eucaristía de la Sagrada Escritura, ya que ambas son alimento y forman una unidad dentro de la celebración eucarística, con la mesa de la palabra y la mesa del pan, que concentra a los fieles en la capilla del Sagrario.

\section{La Capilla del Sagrario Como CaSa de la Sabiduría}

El tabernáculo analizado, compuesto por templete semicircular y capilla cuadrada que evocan el Santo Sepulcro y el patio que se fusionó con él a partir de las

30 SAN AGUSTÍN DE HIPONA, Sermón 227, 1.

31 ID., Sermón 228 B, 3.

32 ID., Epistola 149, 32.

33 ID., Sermón 229, 2.

34 ID., Sermón 131, 1.

35 SAN JeRónImo, Comentarios al Eclesiastés 3, 12. Sobre los comentarios bíblicos de san Jerónimo, véase Comentario Bíblico «San ferónimo», Antiguo Testamento II, dirigido por R. E. BROMN, J. A. FITZMEYER, R.E MURPHY, Cristiandad, Madrid, 1971. 


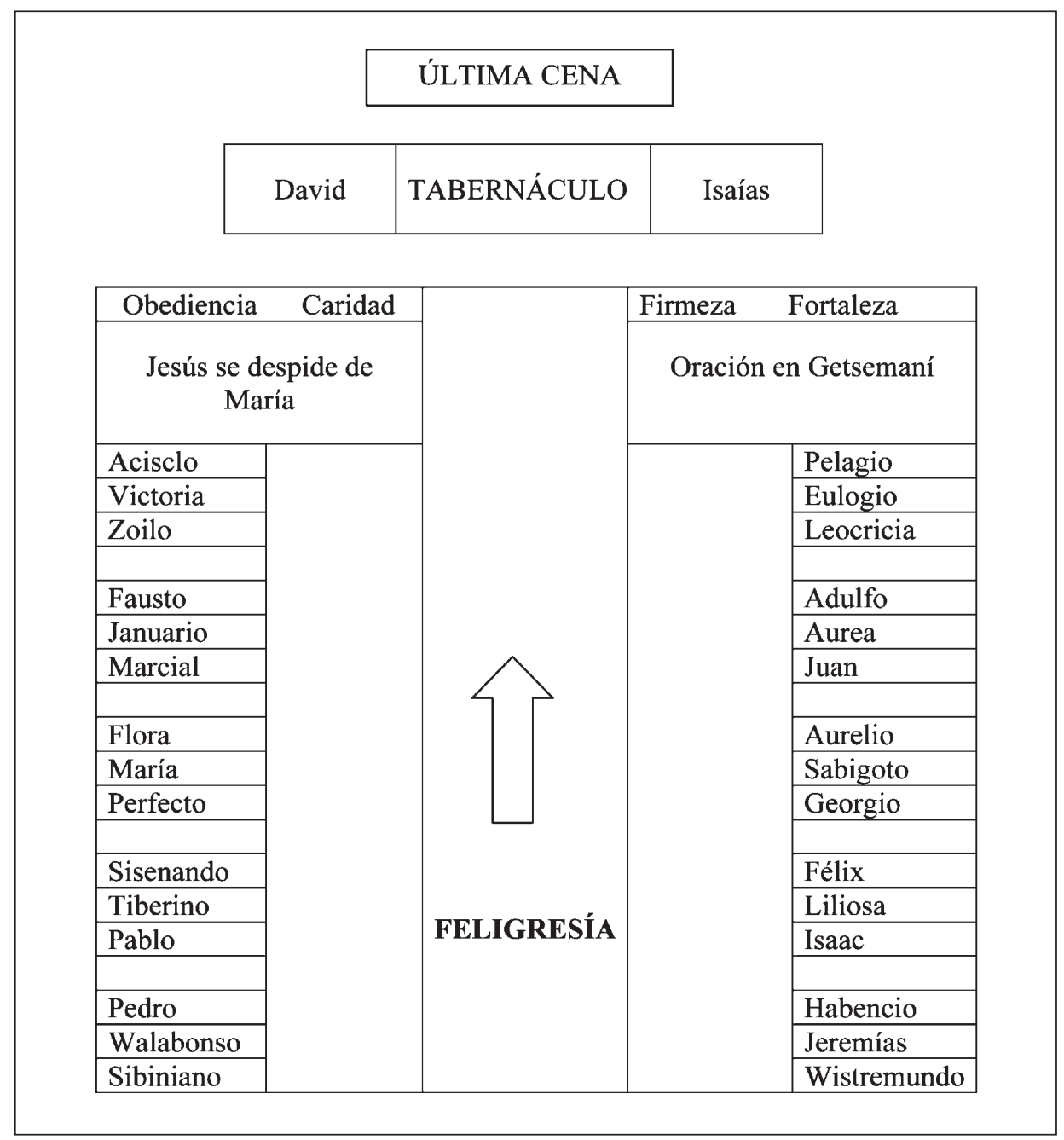

Esquema iconográfico del programa visual de la capilla del Sagrario.

cruzadas $^{36}$, constituye el núcleo central de la capilla del Sagrario de Córdoba, que se correspondería con la basílica martirial del conjunto hierosolimitano comentado. No es de extrañar, pues, que los mártires de la iglesia diocesana adquieran un especial protagonismo en su decoración.

36 Paul DesCHAMPS, Terre Sainte..., op. cit., nota 17, p. 241. 
Los mártires de la Iglesia comparten con Cristo su vida y la ofrecen por Él, que se inmoló como víctima para redimir a la humanidad, sacrificio que se rememora en la celebración eucarística. En este sentido, recordar que san Agustín en su Tratado sobre el evangelio de san fuan explica las palabras del evangelista, «Cristo dio su vida por nosotros; también nosotros debemos dar nuestra vida por los hermanos, amándonos mutuamente como él nos amó», y comenta que es:

la misma idea que encontramos en el libro de los Proverbios: Sentado a la mesa de un señor, mira bien qué te ponen delante, y pon la mano en ello pensando que luego tendrás que preparar tú algo semejante. Esta mesa de tal señor no es otra que aquella de la cual tomamos el cuerpo y la sangre de aquel que dio su vida por nosotros. Sentarse a ella significa acercarse a la misma con humildad. Mirar bien lo que nos ponen delante equivale a tomar conciencia de la grandeza de este don. Y poner la mano en ello, pensando que luego tendremos que preparar algo semejante, significa lo que ya he dicho antes: que así como Cristo dio su vida por nosotros, también nosotros debemos dar la vida por los hermanos ${ }^{37}$.

El autor de los Proverbios recoge la relación de la Sabiduría divina y Cristo, la Sabiduría de Dios (1 Cr 1,30) encarnada (Mt 3,17 y 17,5) ${ }^{38}$, cuyo cuerpo, sangre, alma y divinidad se reserva en la capilla del Sagrario, que sobre el tabernáculo presenta la invitación, «GVSTATE ET VIDETE QVAM / SVAVIS EST DOMUNVS» (Sal 34,9), al doble banquete de la instrucción cristiana -el pan y el vino que constituyen el alimento espiritual contenido en la Sagrada Escritura- y la Eucaristía, el cuerpo y la sangre de Cristo, alimento real del alma.

Bartolomé Menor, en una monografía sobre la parroquia que regentaba, intuyó el sentido de banquete al escribir:

La cena eucarística es el sacramento de esa realidad última y gozosa, que el mismo Jesús anuncia en la parábola del banquete real. / No es descabellado afirmar, aunque el juicio es apasionado y poético, que toda la Capilla está concebida como un precioso comedor de palacio oriental, decorado al gusto renacentista. Es el salón del banquete real. A participar de este banquete estamos llamados todos los hombres. Nos recuerda con numerosos signos de la pasión que, gracias a la muerte y resurrección de Jesús, todos nos sentaremos a la mesa del Reino para participar de la Vida ${ }^{39}$.

37 SAN AGUSTÍN DE HIPONA, Tratado 84 sobre el evangelio de san fuan, 1-2: CCL 36, 536-538.

38 La Sabiduría proclama sus enseñanzas que muestran el camino de la verdadera vida (Prov 8,1-11) como declaró Jesucristo a sus discípulos (Jn 14,6), recogiendo el autor sapiencial que quien ame la Sabiduría y se esfuerce la encontrará (Prov 8,17), lo que se corresponde con la declaración de Jesucristo cuando dijo que quien lo amase y guardase sus mandamientos encontrará al Padre, «vendremos a Él y en Él haremos morada» (Jn 14,23).

39 Bartolomé Menor Borrego, El Templo Parroquial..., op. cit., nota 23, p. 72. 


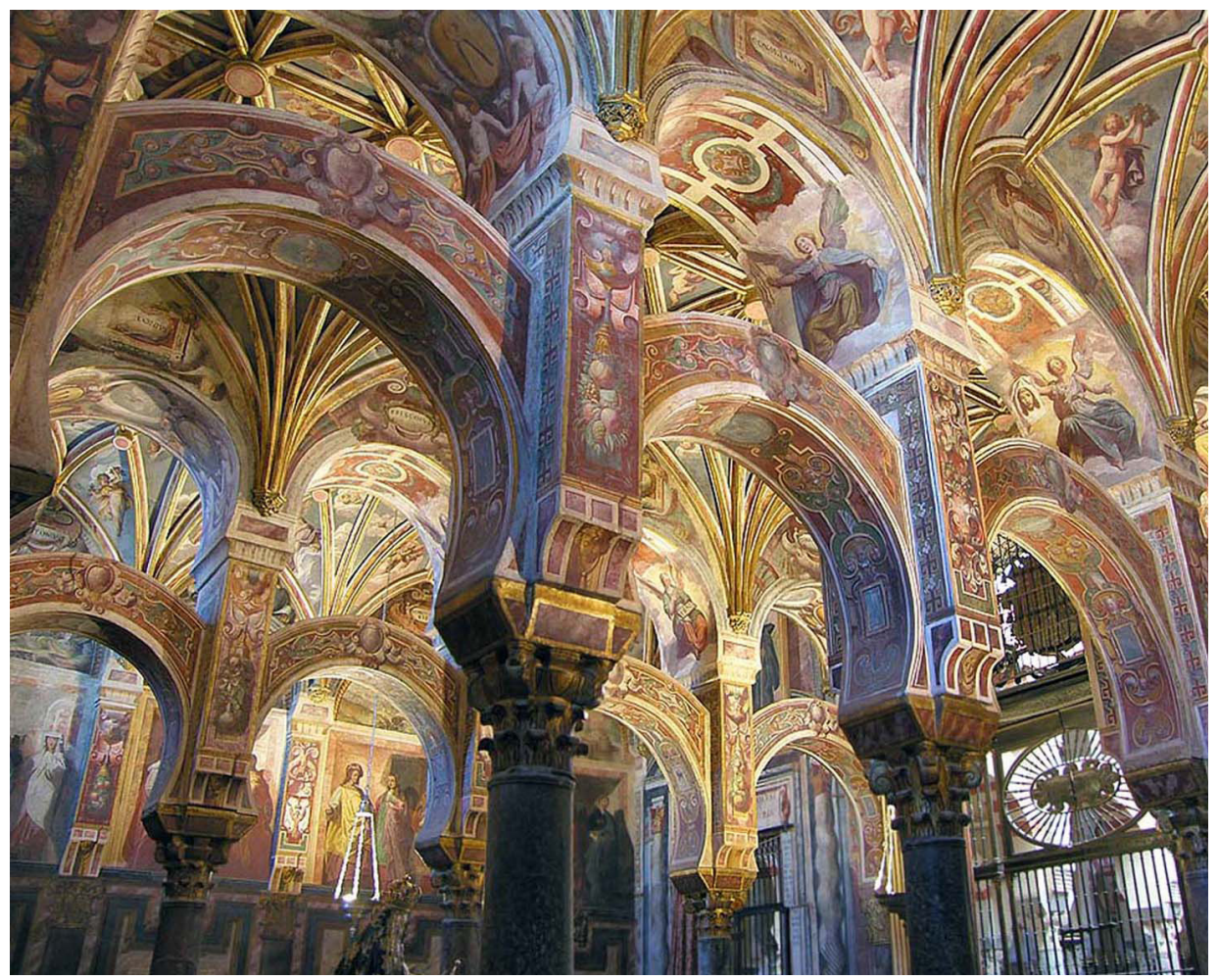

Vista general de la capilla del Sagrario.

Pero, aunque pueda presentar algún paralelismo con el banquete real (Mt 22,1-14), creemos que el programa visual de la capilla del Sagrario recoge el sentido sapiencial del salmista que exhorta a reconocer la protección divina en el frente de la capilla, en el que se invita a gustar la bondad de Dios, de quien procede la felicidad, y de la convocatoria al banquete -que, a veces, en la Sagrada Escritura simboliza el reino de los cielos- que ofrece la Sabiduría, cuya invitación creemos está en la base del programa: «La sabiduría se ha edificado su casa, labró sus siete columnas. Mató sus víctimas, mezcló su vino y aderezó la mesa. Mandó sus doncellas a invitar desde lo alto de la ciudad: El que es simple venga acá, al que no tiene sentido hablo. Venid y comed mi pan y bebed el vino que he mezclado. Dejaos de simplezas y viviréis, y andad por la senda de la inteligencia» (Prov 9,1-6).

La Sabiduría construye su casa, alegoría que se puede identificar con el cuerpo místico de Cristo, la Iglesia, de ahí que sea una imagen perfecta para establecer un paralelismo con un recinto sagrado, presentándolo el autor de los 
Proverbios como una morada suntuosa, como en la realidad se presenta la capilla cordobesa, que posee una rica decoración tanto en los muros con la representación de los mártires cordobeses, a quienes nos referiremos más adelante, como en la cubierta, con grutescos, ángeles y símbolos de la Pasión del Señor.

La Sabiduría construye su lujosa casa sobre siete columnas ${ }^{40}$, que tratándose de una alegoría de la Iglesia, se pueden identificar con los dones del Espíritu Santo que enriquecen las almas de los cristianos, que toman vida por los sacramentos o las virtudes que las sostienen.

En el banquete tiene una gran importancia la víctima, que para Lesêtre es Cristo, inmolado en la cruz de forma cruenta y en el altar de forma incruenta, y junto a Jesucristo están las víctimas inmoladas en la Iglesia, los mártires, que por sus méritos y heroicidad sostienen con Cristo la vida de los cristianos ${ }^{41}$. Asimismo, la bebida que se ofrece, el vino mezclado con agua, es similar al utilizado en la celebración eucarística, donde el pan y vino -el alimento espiritual de la Sagrada Escritura- se transforman en el cuerpo y sangre de Cristo, alimento real del alma.

La invitación al banquete se hace a todos los que quieran recibir los bienes de la Sabiduría, que envía a sus doncellas para que todos conozcan su convocatoria, emisarias que prefiguran a los ministros de la Iglesia, quienes invitan a los fieles al banquete de la celebración eucarística: la mesa de la Palabra y la mesa de la Eucaristía. En definitiva, el doble banquete expuesto a través de las figuras de san Agustín y san Jerónimo que decoran el cuerpo superior del templete interno del tabernáculo, como hemos señalado, no pudiéndose separar la Eucaristía de la Sagrada Escritura, en lo que incide la catequesis de la Iglesia: «Junto a la mesa está el ambón, es decir, el lugar desde el cual se proclama la Palabra de Dios: y esto indica que allí nos reunimos para escuchar al Señor que habla mediante las Sagradas Escrituras y, por lo tanto, el alimento que se recibe es también su Palabra. Palabra y Pan en la Misa se hacen una misma cosa, como en la Última Cena, cuando todas las palabras y signos de Jesús se condensaron en el gesto de partir el pan y ofrecer el cáliz, anticipación del sacrificio de la cruz» ${ }^{42}$.

40 Sobre las siete columnas, que dan idea del esplendor y plenitud de los dones de la Sabiduría, véase Patrick W. SKeHan, The Seven Columns of Wisdom's in Poverbs 9,1, en Catholic Biblical Quarterly, 9 (1947), pp. 190-198.

$41 \mathrm{Al}$ respecto, véase la excepcional interpretación de Henri LESÊTRE, Le libre des Proverbes, París, F. Lethielleux, 1879.

42 Cfr. Papa Francisco, Audiencia General, Plaza de San Pedro, miércoles 5 de febrero de 2014. http://w2.vatican.va/content/francesco/es/audiences/2014/documents/papa-francesco_20140205_ udienza-generale.html [Consultada, 2/12/2016]. 
El programa visual de los frescos pintado por César Arbasia representa el banquete eucarístico que se ofrece a todos los fieles, quienes tienen como ejemplo a los mártires de la iglesia diocesana que se ofrecieron como víctimas.

Como en los relieves del tabernáculo, el conjunto de pinturas presenta prefiguras veterotestamentarias, precisamente flanqueando las puertas del mismo, limitadas por David e Isaías.

David, con su característica arpa y un libro que lo identifica como profeta, tal como se presenta en el crucero catedralicio, está acompañado por una cartela que reproduce las grandezas de las obras de Dios: «Hizo memorables sus maravillas, Yahvé es clemente y misericordioso. Dio de comer a los que le temen, acordándose siempre de su alianza» (Sal 111,4-5), recogiendo el salmista los grandes beneficios de Dios a favor de Israel, al que liberó de la esclavitud e hizo un memorial de sus maravillas, aludiendo a la Pascua que conmemora la liberación de los israelitas del ángel exterminador, encuadrándose en este contexto la Última Cena que preside la capilla.

Isaías recoge el banquete mesiánico (Is 25,6-8) que Yahvé ofrece a todas las naciones, «un festín de suculentos manjares, un festín de vinos generosos» (Is $25,6)$, prefigura del banquete eucarístico instituido en la Cena pintada sobre el tabernáculo.

A sus lados, dos frescos de gran significado fesús despidiéndose de María y la Oración en Getsemaní, enmarcados por arquitecturas fingidas de columnas salomónicas que recuerdan las del templo de Salomón, la casa del Padre, «No hagan de la casa de mi padre una casa de comercio» (Jn 2,13-27), con frontones partidos que sostienen las alegorías de la Obediencia y la Caridad sobre la despedida de Jesucristo y María, y de la Firmeza y la Fortaleza sobre la Oración de Jesús en el Huerto de los Olivos, siguiendo el planteamiento tripartito que se había utilizado en el trasaltar y nártex del crucero construido por don Leopoldo de Austria, continuando ideas neoplatónicas con alegorías centrales que se relacionan con las laterales apoyadas sobre los arcos que sirven de base a los lunetos, con un esquema compositivo que recordaba el desarrollado por Miguel Ángel en la Capilla Medici de San Lorenzo de Florencia. Por otro lado, creemos se quiere subrayar la relación de las alegorías de la Firmeza y la Fortaleza con las columnas salomónicas que recuerdan la de Jaquín y Boaz del templo de Salomón, que a partir de Nicolás de Lyra adquieren el sentido alegórico de firmitas y fortitudo que representan el poder del reino de David ${ }^{43}$ que recibe Jesús, $\ll_{i} B$ Bendito el reino que viene, de

43 Robert Balgarnie Young SCOTT, The Pillars Fachin and Boaz, en Fournal of Biblical Literature, 58 (1939), pp. 143 ss. 
FERNANDO MORENO CUADRO

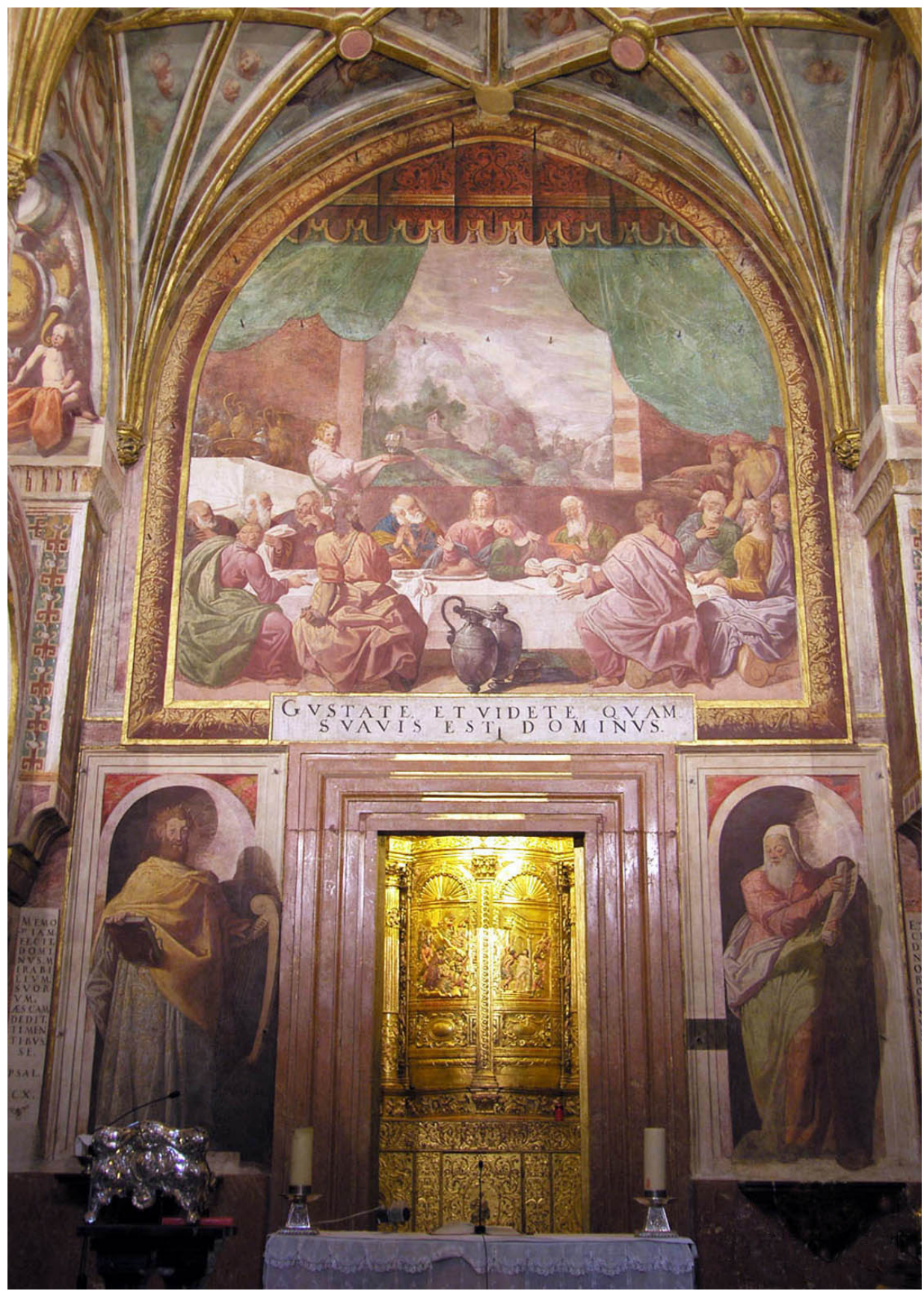

Frente de la capilla del Sagrario con la Última Cena y David e Isaías enmarcando el tabernáculo. 
nuestro padre David!» (Mc 11,12), cuyo reino es la Iglesia, el reino de David que se continúa, siendo el único kirios del reino mesiánico y María la gêbira, que es reina por ser madre de Cristo Rey ${ }^{44}$.

Firmeza y Fortaleza que en el crucero catedralicio se asocian a la iglesia diocesana y se destacan sobre san Sebastián asaeteado y en la capilla del Sagrario se representan sobre la oración de Cristo en Getsemaní preparándose con el Padre para el duro camino que le esperaba.

Las escenas que decoran el frente de la capilla están directamente relacionadas con la Víctima por excelencia, que acepta la voluntad del Padre por amor, «Tanto amó Dios al mundo que entregó a su Hijo único para que no perezca ninguno de los que creen en él, sino que tengan vida eterna» (Jn 3, 14), y con firmeza, sin vacilar, «Yo doy mi vida pero la tomo de nuevo» (Jn 10,17), y venciendo el temor con fortaleza, se encamina al sacrificio después de haberse despedido de María y de sus discípulos en la Última Cena, en la que instituye la Eucaristía, Sacramento que se reserva en el tabernáculo que constituye el centro neurálgico de la capilla.

Cristo es la Víctima, pero junto a Él se ofrecen los mártires, víctimas con Cristo en el banquete que se presentan a la feligresía como modelo a seguir. Así como Cristo se preparó en Getsemaní para la pasión y sacrificio en la cruz que se rememora en la celebración eucarística, los mártires -testigos de la fe que se presentan como modelo a quienes participan en la celebración eucarística que rememora el sacrificio de Cristo en la cruz- se preparaban espiritualmente siguiendo a Cristo en Getsemaní4 ${ }^{45}$, presentándose como ejemplo a la diócesis, que incluyó su culto en los Officia Propria ${ }^{46}$.

Todo el perímetro de la capilla, excepto el frente comentado y la puerta de acceso, está decorado con los frescos de los mártires pintados por César Arbasia ${ }^{47}$, que se distribuyen en grupos de tres, con amplias inscripciones que recogen sus historia y martirios, aunque sus representaciones son incruentas y se encuentran ataviados con ricos ropajes, y sobre ellos paisajes, un género que cultivó especialmente Arbasia.

44 Sobre la realeza de María, véase la Carta Encíclica de PíO XII, Ad Coeli Reginam, de 11 de octubre de 1954.

$45 \mathrm{Al}$ respecto, véase Kenneth Baxter WOLF, Christian martyrs in Muslim Spain, Cambridge University Press, Cambridge, 1988.

46 Officia Propria Cordubensis Ecclesiae: SS. D. N. Gregorii XIII et Clementis VIII auctoritate approbata \& concessa: lectiones aliaquot, \& responsoria, Cordubae, apud Saluatorem de Cea Tesa, 1633.

47 Consúltense los artículos de Manuel PÉREZ LOZANO, Los programas iconográficos..., op. cit., nota 22, pp. 57-64; y Giulia CONTI, Las pinturas del Sagrario de la Catedral de Córdoba, en Homenaje a Dionisio Ortiz fuárez, Consejería de Cultura de la Junta de Andalucía, Diputación de Córdoba y Ayuntamiento de Córdoba, Córdoba, 1991, pp. 45-57. 


\section{El TABERNÁCULO Y LA PUERTA DE JERUSALÉN \\ DE LA CATEDRAL DE CÓRDOBA}

No creemos casual la ubicación de la capilla del Sagrario en la iglesia mayor de Córdoba, especialmente si tenemos en cuenta que coincide en el tiempo con el nuevo crucero catedralicio, concebido como el templo de Salomón ${ }^{48}$. Pensamos que en la Mezquita-Catedral de Córdoba se presenta en conjunto una imagen de Jerusalén -La Nueva Jerusalén de Córdoba-, en la que el tabernáculo y el crucero se corresponden con el Santo Sepulcro y el Templo de Salomón.

Hay varias representaciones de la antigua ciudad de Jerusalén que la figuran con diversas formas, siendo características por sus diferencias la realizada por Matthew Paris's ${ }^{49}$ en el mapa de la ruta de Jerusalén (c. 1250) con la Urbs quadrata $^{50}$ y la del Liber Cronicarum de Hartmann Schedel, publicado en Núremberg en 1493, que la figura circular en torno al Templum Salomonis, al que también reproduce con estructura centralizada, que contradice los textos bíblicos (1 Re 6) $\mathrm{y}$ asocia formas y significados diferentes.

Diversidad de versiones que no tratan de representar un lugar con exactitud sino figuradamente para recordar su importancia simbólica, lo que también ocurrió con las más relevantes construcciones cristianas ${ }^{51}$, idea en la que debemos insistir porque nos interesa subrayar las connotaciones formales e ideológicas de la conciencia colectiva, destacando cómo se pueden producir diferentes concreciones visuales a partir de una idea y cómo a partir de una materialización concreta pueden surgir modificaciones significativas, tal como ocurre con la planta de la antigua aljama de Córdoba, sugiriendo ambos procesos una comparación de ideas y formas, temática planteada por Hautecoeur ${ }^{52}$.

Matthew Paris's en su mapa topográfico de Palestina presenta la ciudad de Jerusalén de forma cuadrada y amurallada, en cuyo interior destacan el Templo del Señor, una construcción centralizada y cubierta por una gran cúpula -La Cú-

48 Fernando Moreno CuAdro, El crucero de la catedral..., op. cit., nota 11.

49 Sobre este cronista benedictino inglés, véase Bjorn WEILER, Matthew Paris on the Writing of History, en Fournal of Medieval History, 35 (2009), pp. 254-278.

50 BRITISH LIBRARY ROYAL, MS 14 C vii, f. 5.

51 Richard KRAUTHEIMER, Introduction to an Iconographie of Medieval Architecture, en Fournal of the Warburg and Courtauld Institutes, 5 (1942), pp. 1-33, vid. esp. p. 17; reimpreso en Studies in Early Christian, Medieval and Renaissance Art, a cargo de James S. ACKERMAN et al., New York University Press, New York, 1969.

52 Louis Hautecoeur, Mystique et architecture: Simbolisme du cercle et de la coupole, Picarde, París, 1954, f. XI. 
EL TABERNÁCULO DE GUILLERMO DE ORTA PARA LA CAPILLA DEL SAGRARIO...

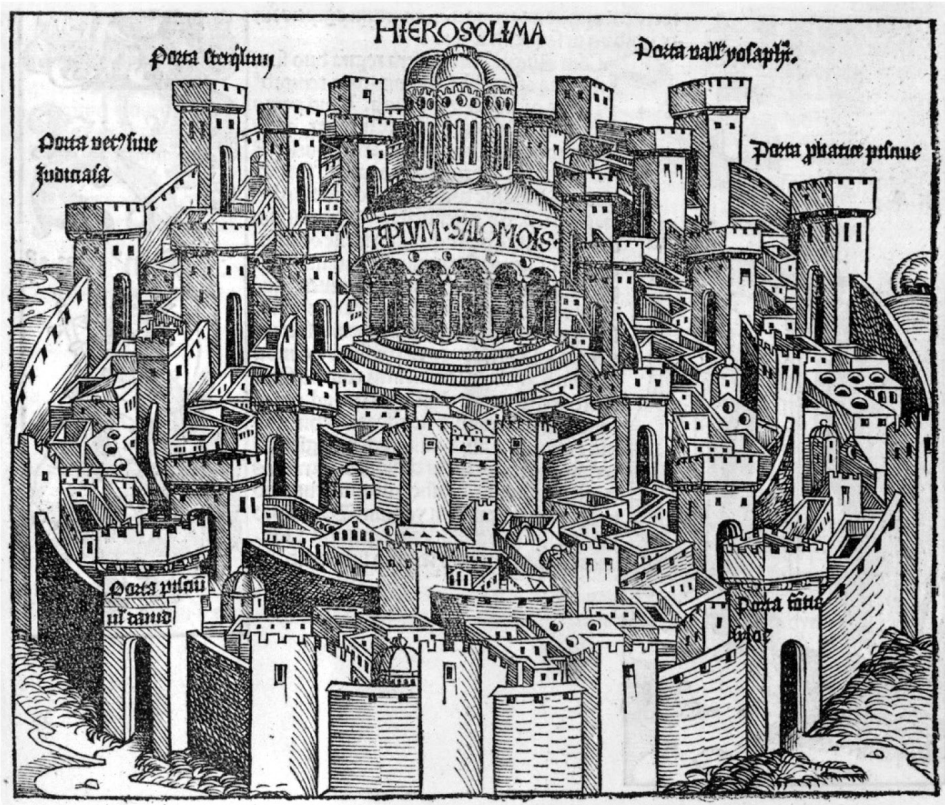

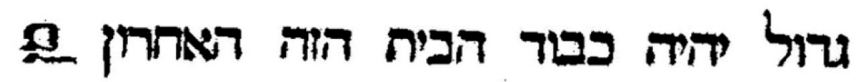

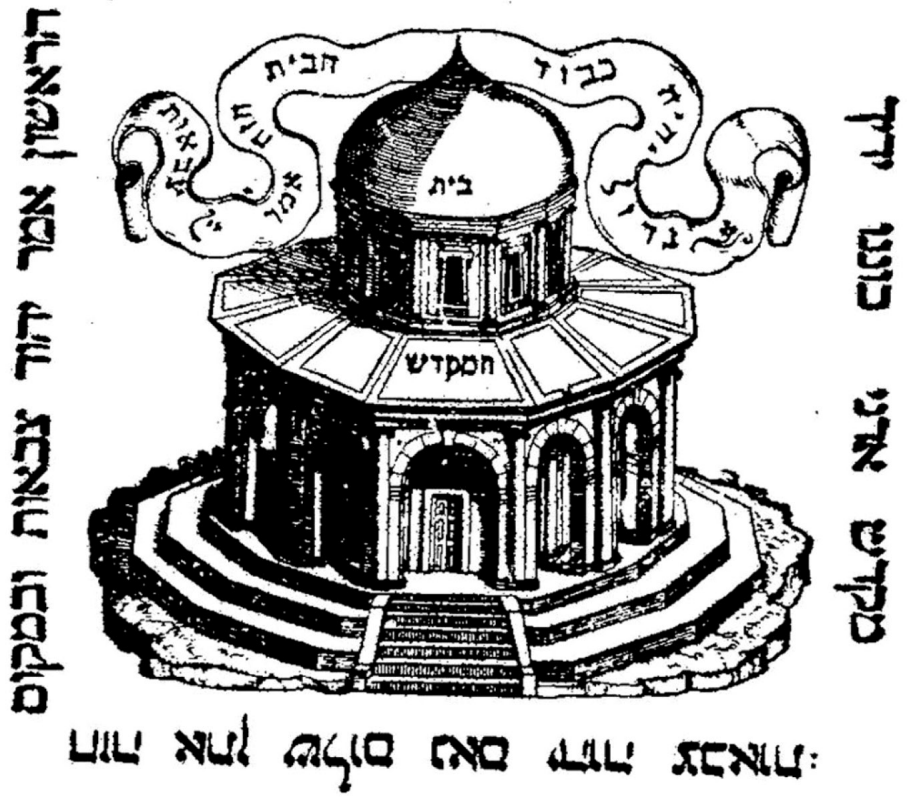

Entalladuras de la ciudad de Jerusalén por Maichael Wolgemut para Las Crónicas de Núremberg de Hartmann Schedel, 1493 (arriba) y del Domo de la Roca, 1546 (abajo). 
pula de la Roca- que consagraron los templarios y se identificó en buena parte de occidente como el Templo de Salomón, que el famoso cronista figura mediante una estructura longitudinal frente a él, sobresaliendo asimismo el Santo Sepulcro como un edificio centralizado en el que destaca un añadido cuadrado que se podría identificar con el patio que lo conectaba con la basílica martirial constantiniana o el espacio surgido tras la remodelación de los cruzados.

Para nuestro propósito, interesa recordar lo señalado en relación a las distintas materializaciones visuales - condicionadas por el contexto- de ideas y cómo estas pueden enriquecerse con determinados significados, como se produce en la Mezquita-Catedral de Córdoba que, exceptuando el patio de los Naranjos, tiene una planta cuadrada con contrafuertes que en planta semejan las murallas de una ciudad, similar a la que presentan algunas representaciones de Jerusalén, entre ellas la comentada de Matthew Paris's.

Cuando fue consagrada, después de la conquista de la ciudad de Córdoba por Fernando III, se convirtió en un espacio sagrado y, como tal, en una representación de la Jerusalén Celeste ${ }^{53}$, siguiendo el sentido reproductor de la arquitectura, especialmente desarrollado por Sedlmayr, quien planteó la catedral gótica como una reproducción de la ciudad celestial ${ }^{54}$, y Kitschel que comparó la basílica paleocristiana con la Jerusalén Celeste estableciendo un parangón entre los elementos urbanos y arquitectónicos ${ }^{55}$.

De la misma manera que la Jerusalén celestial se refleja en los templos, podemos apreciar asimismo la relación de la ciudad celeste con la ciudad real, siendo un ejemplo especialmente ilustrativo la decoración del ábside de la basílica de Santa Prudenciana de Roma, de época teodosiana (390), en la que aparece Cristo entronizado, rodeado de apóstoles ,y santa Prudenciana y su hermana Práxedes coronando a san Pedro y san Pablo ante una representación simbólica de Jerusalén, en la que destaca la cruz de gemas que Constantino mandó colocar en el Calvario, rodeada por los símbolos de los evangelistas.

En Córdoba, por los procesos señalados, la catedral se identifica con la Jerusalén Celestial y la planta de la antigua aljama con la Jerusalén real, que se recuerda a través de una de las puertas del edificio, La puerta de ferusalén, ubicada

$53 \mathrm{Al}$ respecto, véase Alfonso RODRÍGUEZ GUTIÉRREZ DE CEBALLOS, El simbolismo de la «ferusalén Celeste» constante ambiental del Templo cristiano, en El arte sacro y el concilio Vaticano II, León, 1965, p. 145.

54 Hans SEDLMAYR, Épocas y obras artísticas, Rialp, Madrid, 1965, t. II, pp. 213-216.

55 Lothar KITSCHELT, Die frühchristliche Basilika als Darstellung des bimmlischem ferusalem, en la serie Münchener Beitrr. Zur Kunstgeschichte, Bd. 3, Neuer Filser-Verlag, Múnich, 1938. 

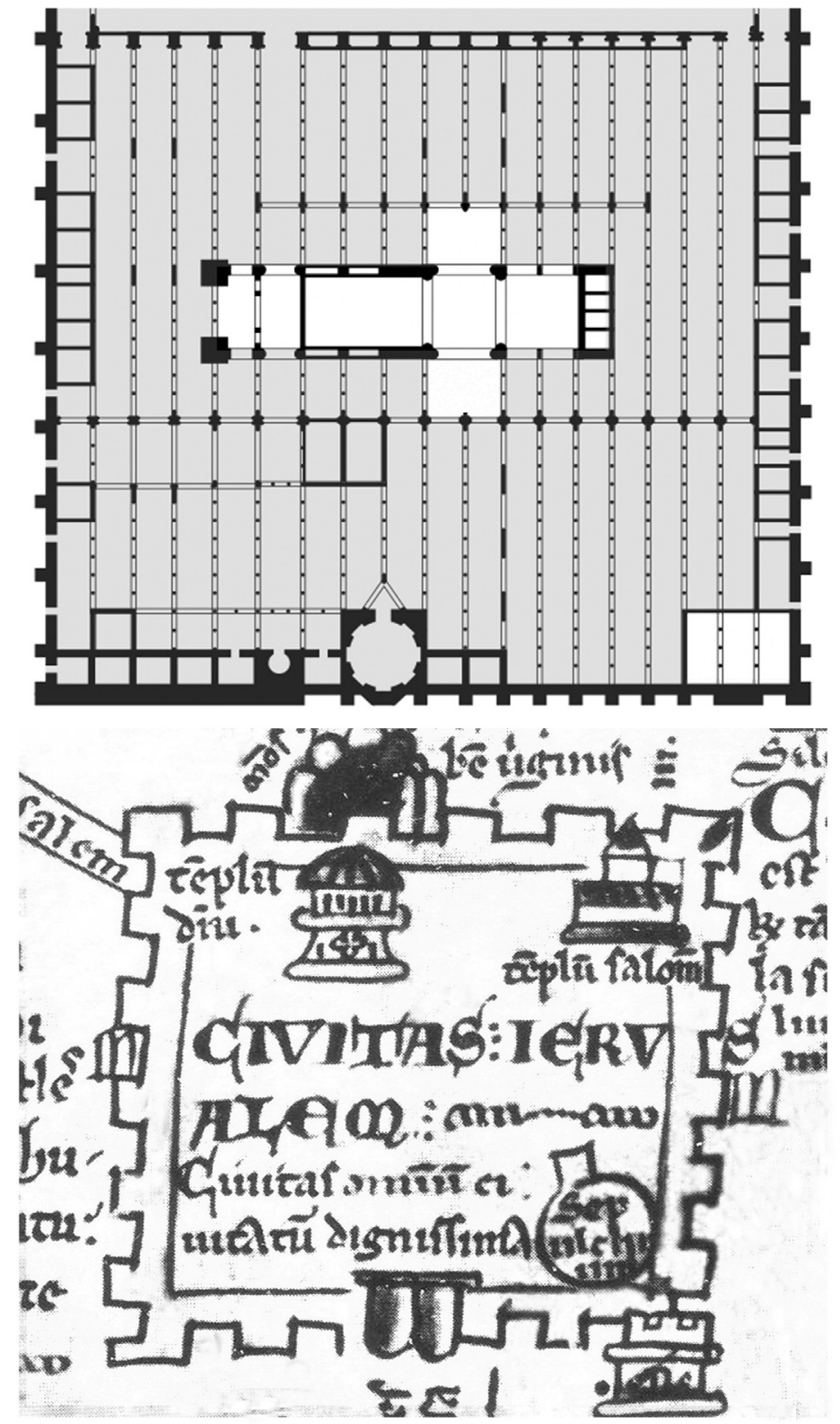

Planta esquemática de la Mezquita-Catedral de Córdoba con la señalización del crucero y capilla del Sagrario (arriba) y plano de la ciudad de Jerusalén por Matthew Paris's (c. 1250) con la señalización del Templo del Señor, Templo de Salomón y Santo Sepulcro (abajo). 


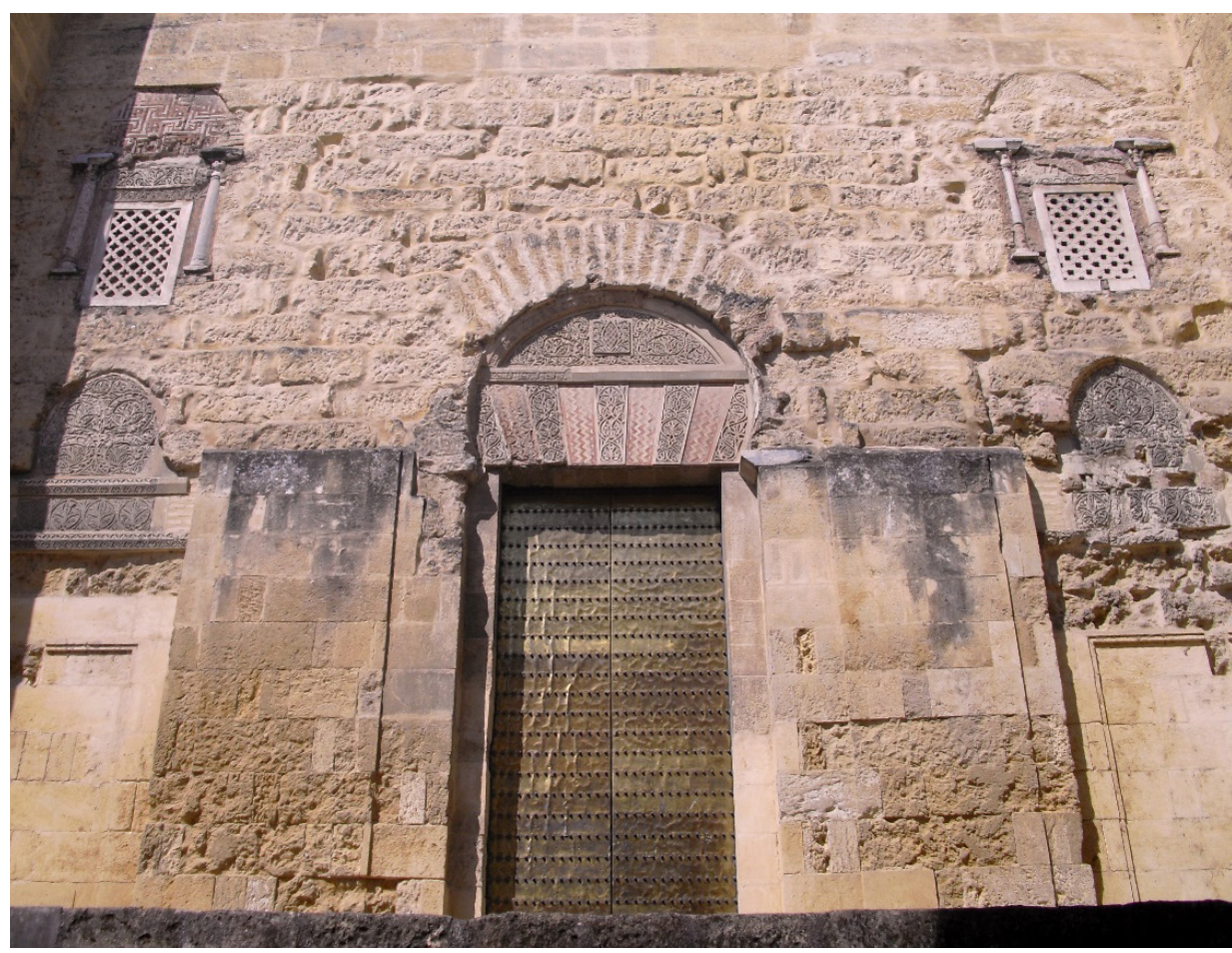

Puerta de Jerusalén de la Mezquita-Catedral de Córdoba.

en el extremo sur de la fachada este, correspondiente a la ampliación de Almazor, cuya denominación aparece como punto de referencia en las Actas Capitulares del 7 de enero de 1517, cuando se plantea la construcción de la Biblioteca Capitular, emplazamiento de la capilla del Sagrario: «Este día los señores deán y cabildo con acuerdo del señor don Pedro Manrique, provisor deste obispado, mandaron que la librería que agora se haze en esta iglesia en la capilla de Santiago, vaya continuando y empeñando con la pared de la Capilla hasta dar en el adarve de la iglesia que es en medio de la puerta que dizen de Iherusalem $\gg^{56}$.

Cuando en el siglo XVI se construye el nuevo crucero catedralicio se plantea un parangón con el templo de Salomón, la construcción más prestigiosa de todos los tiempos, porque -según Flavio Josefo, Anti. Iud. 8,30- fue levantado con la cooperación especial de la divinidad, y coincidiendo con la última etapa construc-

56 Cfr. Manuel Nieto Cumplido, La Catedral de Córdoba..., op. cit., nota 6, p. 383. 
tiva del mismo se realiza la nueva capilla del Sagrario que se ubica junto a la denominada puerta de Jerusalén de la catedral cordobesa, en el ángulo suroriental del espacio edificado, coincidiendo con la ubicación de la Anástasis en la Jerusalén real figurada por Matthew Paris's a mediados del siglo XIII.

Ya hemos comentado la relación de las diferentes partes del conjunto hierosimilitano con la capilla del Sagrario de la catedral de Córdoba, a la que el Cabildo se dirigía para la reserva del Santísimo desde el crucero-templo de Salomón en procesión interna que recordaba, continuando la rememoración del sacrificio de Cristo en la Eucaristía, su entierro -colocación del Sacramento en el que está real y substancialmente el cuerpo, la sangre, el alma y la divinidad de Jesucristo-a través de la reserva en el tabernáculo de la capilla del Sagrario, imagen del Santo Sepulcro de Jerusalén. 
